\title{
Sub-Chronic Effects of MethanolicBenth Bark Extract Of BrideliaFerrugineaon Some Selected Biochemical Indicesin Rats
}

\author{
${ }^{* 1,2}$ Salau, B. A., Adeleke Atunnise ${ }^{1}$, Oluwaseyi OSodipo ${ }^{1}$, Oluwafemi E. Kale ${ }^{3}$, \\ E. O. Ajani ${ }^{4}$ \\ ${ }^{I}$ Department of Biochemistry, ObafemiAwolowo College of Health Sciences, Ikenne Campus, OlabisiOnabanjo \\ University, Ago-Iwoye, Ogun State. \\ ${ }^{2}$ Department of Chemical Sciences, College of Natural Science, Redeemer's University, Km 46, Lagos/Ibadan \\ Expressway, PMB 3005, Redemption City Mowe, Ogun State, Nigeria \\ 3Department of Chemical Pharmacology, ObafemiAwolowo College of Health Sciences, Ikenne Campus, \\ OlabisiOnabanjo University, Ago-Iwoye, Ogun State. \\ ${ }^{4}$ Department of Bioscience and Biotechnology, College of pure and Applied Sciences, Kwara State University, \\ Ilorin, Nigeria
}

\begin{abstract}
Recently, there have been growing concerns over the reliance and safety of untested and unregulated plant remedies. Brideliaferruginea is one of the herbal plants commonly used, of which chronic toxicity studies are yet to be examined. Sub-chronic toxicological effects of methanolicbenth bark extract of brideliaferruginea on biochemical indices in rats were evaluated. Three groups of six animals each were used in this study. Group 1 (control)received no treatment. Group 2 and 3 (treated)received calculated doses of $250 \mathrm{mg} / \mathrm{kg}$ and $500 \mathrm{mg} / \mathrm{kg}$ of the extract orally for four weeks. All animals were sacrificedusingdiethylether anesthesia 24hours after the last dosing and blood samples taken. Periodic weights and packed cells volume(PCV) were measured, portions of the heart and brain were excised, homogenized and used for bioassays. From our results, we observedsignificant decrease ( $p<0.05)$ in PCV; superoxide dismutase in Heart and Brain; and brain catalase. No significant effect $(p>0.05)$ was observed in heart and brain;reduced glutathione; catalase, also no effect was observed in lipid peroxidation of heart and brain. However, the two doses kept the weight constant for a period of four (4) weeks. Overall, thebark extract of brideliaferrugineamay affect antioxidant and blood status as well as keeping body weight constant. We suggest therefore thatdoses approaching or above $250 \mathrm{mg} / \mathrm{kg}$ body weight should be avoided by individuals or in herbal preparations.
\end{abstract}

Keywords:Herbal plants, Brideliaferrugineabenth bark, Antioxidants, PCV and Body weight.

\section{Introduction}

Traditionally, herbs and herbal products have been considered to be non-toxic and have been used to treat a range of ailments(Bodeker et al., 2005) however, about three billion of the world's population, living in developing countries now consume herbal medicines as their source of primary health care (Bodeker et al., 2005; Ernst,2000;Farnsworth et al., 1984). Commonpractice among the populace is the use of herbal preparations as prophylactic measure even when apparent disorders or symptoms are absent. Studies have shownacute toxicities resulting from the use of herbs on many occasions. Still, the potential toxicity of several herbs and herbal products has not been recognized (Chan, 2003).Convincingly, with the many ongoing pharmacological screening tests, ithas beenfound that pharmacologically inactive substances may interfere with or enhance the potency of activecompounds (Jowell, 1999; Chan, 2003), which may affect the body adversely.

Brideliaferruginea, which is the commonest savannah bridelia, has attracted several importance to itself and the populace. Studies have shown its anagelisics and antipyretic(Akuodoret al., 2011) antimicrobial activity (Adeoye et al., 1998) and water purification properties (Kolawole and Olayemi 2003).Itsleaves and fruits were used locally as purgative and vermifuges (Cimanga et al., 1999). Iwu (1984) describeditsmolluscidal activity.Other studies described its anti-diabetic properties(Adewale and Oloyede, 2012;Lotikar and RajaramaRao, 1966) among other usefulness.

However, in spite all these, it is evident that the fact that something is natural does not necessarily make it totally safe or effective. This is because majority of the active ingredients of plant extracts are also chemicals and as thus, are similar to those in purified medications. Therefore, they may due to chance by no exceptions possess the same potentials to cause serious adverse effects (Cupp, 1999; D'Arcy, 1993; D'Arcy, 1991).

Till now, studies involving biochemical changes of the methanolic bark extract of brideliaferruginea on vital organs such as heart and brain have not being reported. Thus, in this present study, we evaluated the possible effects of the methanolic bark extract of brideliaferruginea on biochemical indicesduring a sub-chronic dosing in rats in order to ascertain the in vivosafety and efficacies of biochemicalactivities of this plant. 


\section{Material And Methods}

\section{1) PLANT MATERIALS AND PREPARATIN OF EXTRACTS}

Some fresh barkbrideliaferruginea were collected at around 3:30 pm from the Awolowo mini-market, some few miles away from the College of health Sciences, OlabisiOnabanjo University, Sagamu, Ogun state, Nigeria. The identification and authenticity of the plant was done at the Forestry Research Institute, Ibadan, Nigeria.

Exactly $200 \mathrm{~g}$ of the pulverized sucker was soaked in $70 \%$ methanol for 48 hours, the extract was filtered and then concentrated with rotary evaporator. The dried product was kept in air tight contain and the required dose was reconstituted in daily basis and administered.

\section{2) EXPERIMENTAL SUBJECTS AND MANAGEMENT}

Eighteen (18) albino rats (males and females) of average weight $200 \mathrm{~g}$ were obtained from the animal house of the University of Ibadan, Oyo-State, Nigeria. The rats were housed within the experimental animal handling facility of the Department of Biochemistry, Faculty of Basic Medical Sciences, OlabisiOnabanjo University, Ogun State, Nigeria at ambient temperature and humidity with a $12 \mathrm{~h} \mathrm{light} / 12 \mathrm{~h}$ dark schedule. These rats were placed on rat chowduring the two weeks of acclimatization and experimental period. Study was in accordance with established guidelines for care and use of the laboratory animals in biomedical research.

\section{3) ANIMAL GROUPING}

G1: Normal control

G2: $\quad$ Group administered with $250 \mathrm{mg} / \mathrm{kg}$ body weight of methanolic extract of brideliaferruginea

G3: $\quad$ Group administered with $500 \mathrm{mg} / \mathrm{kg}$ body weight of methanolic extract of brideliaferruginea All administration was oral, as a single dose using orally intubator on a daily basis for a period of four (4) weeks.

\section{4) LABORATORY ANALYSIS}

Body weight of the rats were checked on weekly basis for the period of four (4) weeks.Packed Cell Volume (PCV) was measured by using method of Dacie and Lewis (1991); superoxide dismutase (SOD) activities was analyzed using method of Marklundand Marklund 1974 whilst reduced glutathione (GSH), catalase activities and lipid peroxidation (LPO) were carried out using methods of Beutler et al. (1963), Sinha(1972) and Varshney and Kale (1990) respectively.

\section{5) STATISTICAL ANALYSIS}

The data were analyzed using one-way ANOVA, Level of significance was assessed using Duncan Multiple range (DMRT) at $\mathrm{p}<0.05$ (SPSS 14.0 software was used for data analysis).

\section{PHYTOCHEMICAL TESTS}

The methanolic bark extracts of brideliaferrugineawere tested for the presence of some vital plant active ingredients. As described bySofowora (1982)

\section{RESULTS}

\begin{tabular}{|c|c|c|}
\hline \multicolumn{3}{|c|}{$\overline{\mathrm{g} \text { tests of the methanolic bark extracts of Brideli }}$} \\
\hline ACTIVE CONSTITUENTS & rf. Value & CONCENTRATIONS \\
\hline$\overline{\text { Alkaloids }}$ & 0.46 & +++ \\
\hline Tannins & 0.30 & ++ \\
\hline Saponins & 0.85 & + \\
\hline Terpenoids & 0.39 & ++ \\
\hline Steroid & 0.56 & + \\
\hline Phlobatannins & & ++ \\
\hline Glycosides, Flavonoids & $0.30-0.85$ & - \\
\hline Anthraquinones & 0 & - \\
\hline
\end{tabular}

Keys: ++ = Highly present; + = Present; - = Not present; rf. indicates retention factor with respect to concentration. 


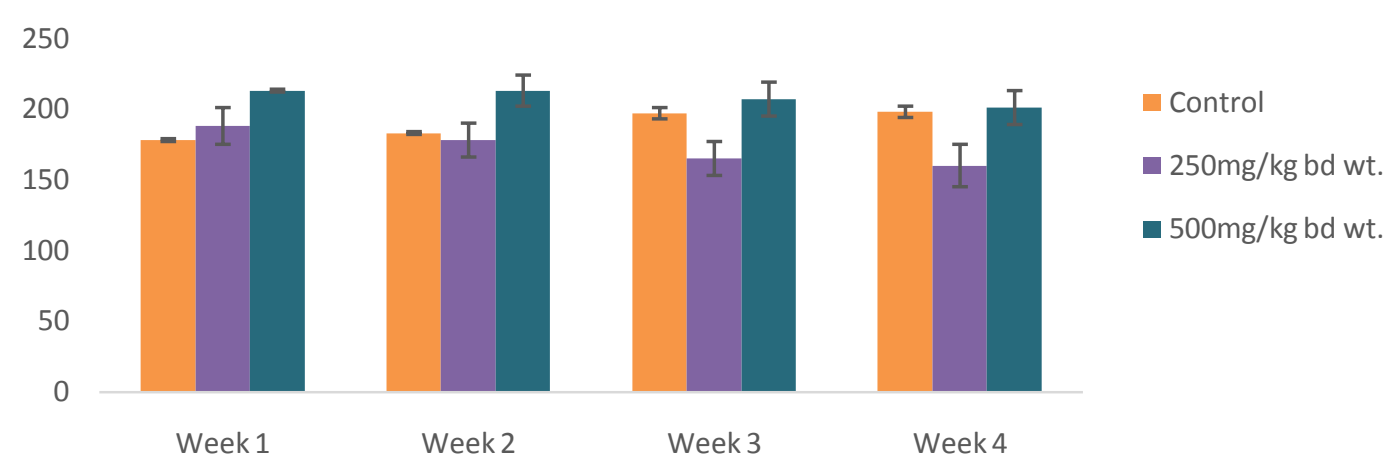

Fig 1: Effect of different concentrations of Methanolic extract of Bridelia Ferruginea extract on body weight in gram (g)

TABLE 2: Effects of sub-chronic administration of methanolic bark extracts of brideliaferrugineaon packed cells volume in rats.

\begin{tabular}{llc}
\hline Rat group & PCV\% & \% change from control \\
\hline G1 & $51.10 \pm 3.64$ & \\
G2 & $41.00 \pm 0.84^{\mathrm{a}}$ & -19.77 \\
G3 & $42.8 \pm 2.22^{\mathrm{a}}$ & -16.24
\end{tabular}

Means \pm SEM for 6 rats per group, Values within a column with superscripts are significantly different at $p<0.05$ when compared with control (G1).

TABLE 3: Effects of sub-chronic administration of methanolic bark extracts of brideliaferruginea on superoxide dismutase (SOD) activities in heart and brain in rats.

\begin{tabular}{llclr}
\hline Rat group & Heart & $\begin{array}{c}\text { \% difference } \\
\text { from Control }\end{array}$ & Brain & $\begin{array}{l}\text { \% difference } \\
\text { from Control }\end{array}$ \\
\hline G1 & $30.18 \pm 4.30$ & & $21.11 \pm 3.22$ & \\
G2 & $15.32 \pm 4.32^{\mathrm{a}}$ & -49.24 & $16.67 \pm 0.42^{\mathrm{a}}$ & -21.03 \\
G3 & $13.18 \pm 2.04^{\mathrm{a}}$ & -56.33 & $12.66 \pm 1.34^{\mathrm{a}}$ & -40.03
\end{tabular}

Means \pm SEM for 6 rats per group, Values within a column with superscripts are significantly different at $p<0.05$ when compared with control (G1).

TABLE 4: Effects of sub-chronic administration of methanolic bark extracts of brideliaferrugineaon reduced glutathione (GSH) levels in heart and brain in rats.

\begin{tabular}{lll}
\hline Rat group & Heart $\underline{\text { GSH }(\mu \mathrm{mol} / \mathrm{mg} \text { protein })}$ & \\
\hline G1 & $1.90 \pm 0.54$ & $1.42 \pm 0.31$ \\
G3 & $1.84 \pm 0.21$ & $2.50 \pm 0.35$ \\
G4 & $2.39 \pm 0.25$ & $2.31 \pm 0.28$ \\
\hline
\end{tabular}

Means \pm SEM for 6 rats per group. 
TABLE 5: Effects of sub-chronic administration of methanolic bark extracts of brideliaferruginea on catalase (CAT)activities in heart and brain in rats.

\begin{tabular}{lllcl} 
Rat group & Heart & $\begin{array}{l}\text { CAT }\left(\mu \mathrm{molH}_{2} \mathrm{O}_{2} / \mathrm{min}\right) \\
\text { f difference } \\
\text { from Control }\end{array}$ & Brain & $\begin{array}{l}\% \text { difference } \\
\text { from Control }\end{array}$ \\
\hline $\mathrm{G} 1$ & $3.00 \pm 0.66$ & & $55.83 \pm 14.62$ & \\
$\mathrm{G} 2$ & $5.16 \pm 1.10$ & 72.0 & $14.01 \pm 0.60^{\mathrm{a}}$ & -74.91 \\
$\mathrm{G} 3$ & $3.5 \pm 0.50$ & 16.67 & $15.48 \pm 0.36^{\mathrm{a}}$ & -72.27
\end{tabular}

Means \pm SEM for 6 rats per group, Values within a column with superscripts are significantly different at $\mathrm{p}<0.05$ when compared with control (G1).

TABLE 6: Effects of sub-chronic administration of methanolic bark extracts of brideliaferruginea on lipid peroxidation (LPO) levels in heart and brain in rats.

\begin{tabular}{lll}
\hline Rat group & Heart $\underline{\text { LPO }(\mu \mathrm{mol} / \mathrm{mg} \text { protein })}$ & Brain \\
\hline G1 & $4.23 \pm 1.06$ & $1.74 \pm 1.02$ \\
G2 & $4.58 \pm 0.72$ & $4.01 \pm 1.06$ \\
G3 & $6.30 \pm 0.46$ & $2.29 \pm 1.33$ \\
\hline
\end{tabular}

Means \pm SEM for 6 rats per group.

As shown in table 1: The methanolic bark extracts of brideliaferrugineawere tested for the presence of some vital plant active ingredients. We vary the retention factor (rf.) from 0.30, 0.39, 0.46, 0.56 to 0.85 ; alkaloids, tannins and terpenoids were highly present than flavonoids,saponins and steroid in this extract at varying rf.Values as indicated by table 1. Other active ingredients which tested negative were glycosides, anthraquinones, as seen in this study.

Figure 1showed body weights in grams forthe period of four weeks. Increase $(\mathrm{p}<0.05)$ in weight was observed when the initial and final weights of the control group were compared. However, no significant ( $p>0.05)$ difference was observed with the initial and final weights of the extract treated groups.

Table 2showed the PCV of control and experimental groups treated with methanolic extract of brideliaferruginea. A significant decrease $(\mathrm{p}<0.05)$ was observed when the experimental groups (G2: $41.00 \pm 0.84 ; \mathrm{G} 3: 42.80 \pm 2.22)$ were compared with the control group $(51.10 \pm 3.64 \%)$.

Table3, is the Superoxide dismutase, significant decrease $(\mathrm{p}<0.05)$ was observed in Heart and Brain when the experimental groups were compared with the Control group.

Table 4showed the reduced glutathione of control and experimental groups brideliaferruginae, No significant difference $(p>0.05)$ was observed in both control and treated groups.

Shown in table 5 is the catalase activities levels of control and brideliaferrugineamethanolic extract treated groups. Significant decrease was observed in catalase activities in the brain when control group was compared with experimental groups. However, such effect was not observed $(\mathrm{p}>0.05)$ in the heart tissues.

Table 6 depicts lipid peroxidation of rats treated with brideliaferruginaemethanolic extract, no significant difference was observed ( $>0.05$ ) when the control groups were compared with experimental groups in the heart and brain tissues.

\section{Discussion}

Chemicals, whether synthetic or natural has the capacity to be toxicand plants are no exception. The use of phytomedicineexpecially in developing countries is now increasing in leaps and bounds with apparent confidence that the natural is less toxic. However, this resurgence use of herbal drugs has been reported to be accompanied by increasing risks of adverse effects associated with herbal active ingredients (Chan, 2003). In our study, we evaluated the possibleeffects of methanolic bark extract of brideliaferruginea on biochemical indicesduring a sub-chronic oral administration in rats. From the result of this study, the phytochemical 
screening of methanolic bark extracts of brideliaferruginea, showed the presence of bioactive compounds which may singularly or synergeticallyaffect the biochemical parameters observed.

The constancy in weight of the brideliaferrugineamethanolic treated rats may be as a result of components such as saponin (Gogelein and Huby, 1984)and high level of tannin (Mukuru et al., 1992) which have been shown to be growth depressant by complexing protein. Thus, its intake may be of benefit for weight maintenance and reduction, but may have adverse effect on growing children worse still the teratogenic effect on growing foetusis plausible if used during pregnancy.

Reduction in PCV observed $(\mathrm{p}<0.05)$ could be attributed to the presence of tannins which binds metals such as ferrous required for red blood cell formation (Karamac et al., 2009) and saponin which may interfere with the red blood cell status (Takechi and Tanakar, 1995), thusmay cause aenemia in a long term.However, moderate use of the extract may improve haemorrhological status of the blood as a result of reduced PCV (Lowe, 1993) which may have positive effect on cardiovascular health.

The significant decrease in superoxide dismutase activities observed in rat (heart and brain) treated with Brideliaferrugineamethanolic extract could be as a result of possible decrease in blood protein that might have been caused by saponin and tannin present in extract, moreover, the chelating effect of tannin on Copper and Zinc (Karamac, 2009) may adversely affects the level of SOD both in cytosol and mitochondria.

Catalase is one of the first line antioxidant enzymes in the defense against free radicals (Lammi-Keefe et al 1984).Its level is affected by feed intake and free radicals concentration (de Castro1 et al., 2009). The plausible reduction in catalase observed in brain tissue may be as a result of toxic effect of saponin that may complex or reduce protein utilization (Rashef et al., 2006). And high content of tannin and phlobtanin which reduce the level of iron that is necessary for production of catalase (Lavin, 2010).

Insignificant difference ( $p>0.05)$ observed in lipid peroxidation might indicate the level of free radical production or reduction in antioxidant activities which does not reach a critical stage that may affect the body adversely. However, the reduction in PCV and lack of increase in weight may have either positive or negative impact.

\section{Conclusion}

This result demonstrated the effect of methanolic extract of Brideliaferruginea at different concentrations which may reduce PCV, catalase in the brain; prevents body weight increase and may not have adverse effect on superoxide dismutase, reduced glutathione and lipid peroxidation.

\section{AKNOWLEDGEMENT}

We acknowledgment the following people AinaOlubusayoOmotoyosi, DosumuSekinatMonilola, OdubanjoMorenikeTitilope and UmezurikeOgadinma Theresa for their support during sample collection and laboratory analysis, also Ti-OluwaniSalau for typing the manuscripts.

\section{References}

[1] Adeoye AO, Abaeli AM, Owowumi CJ, Olukoya DK (1998).Antimicrobial activity of Brideliaferrugineain: Book of abstract of the Symposium on drug production from natural product. Drug Research and Production Unit, ObafemiAwolowo University Ile-Ife, p. 24.

[2] Adewale OB and Oloyede OI (2012) Hypoglycemic activity of aqueous extract of the bark of Brideliaferrugineain normal and alloxan-induced diabetic rats Prime Research on Biotechnology2(4), 53-56,

[3] Akuodor G. C., Mbah C. C., Anyalewechi N. A., Idris-Usman M. Iwuanyanwu T. C. and Osunkwo U. A.(2011) Pharmacological profile of aqueous extract of Brideliaferrugineastem bark in the relief of pain and fever. Journal of Medicinal Plants Research 5(22), .5366-5369,

[4] Beutler, E., O. Duron and B.M. Kelly, 1963. Improved method for the determination of blood glutathione. J. Lab. Clin. Med., 61: 882-888.

[5] Bodeker, C., Bodeker, G., Ong, C.K., Grundy, C.K., Burford, G., Shein, K. (2005) WHO Global Atlas of Traditional,Complementary and Alternative Medicine. World Health Organization, Geneva.

[6] Chan K. (2003). Some aspects of toxic contaminants in herbal remedies: A review. Chemosphere 52: 1361-1371

[7] Cimanga K, DeBruyne T, Apers S, Dietersh, Totte J, Kambu K, TonaL,Bakana P, Vanufford LQ, Benkelman C, Labadie R, Veietinck AJ(1999). Complement-inhibiting constituent of Brideliaferrugineastem bark planta Med., 65: 213-217.

[8] Cupp MJ. Herbal remedies: adverse effects and drug interactions. Am Fam Physician. 1999 Mar 1;59(5):1239-1245. [PubMed]

[9] Dacie, J. V. and Lewis, S. M. (1991): Practical Haematology. Churchill Livingstone. Edinburgh. Seventh edition. Pp 521534.

[10] D'Arcy PF. Adverse reactions and interactions with herbal medicines. Part 1. Adverse reactions. Adverse Drug React Toxicol Rev. 1991 Winter;10(4):189-208. [PubMed]

[11] D'Arcy PF. Adverse reactions and interactions with herbal medicines. Part 2--Drug interactions. Adverse Drug React Toxicol Rev. 1993 Autumn;12(3):147-162. [PubMed]

[12] de Castro1, M.A.C F.F. Cavalcanti Neto1, L.M.C. Lima1, F.M. da Silva1, R..J. de Oliveira, A. ZanescoProduction of free radicals and catalase activity during acute exercise training in young men (Biol.Sport 26:113-118, 2009)

[13] Ernst, E (2000) Herbal medicines: where is the evidence?BMJ2000;321:395

[14] Farnsworth, N.R., Akerele, O., Bingel, .S., Soejarto, D.D., Guo, Z. (1985) BullWorldHealth Organ, 63, (6) 965-981.

[15] Gogelein H \&Huby A (1984) Interaction of saponin and digitonin with black lipid membranes and lipid monolayers. BiochemicaetBiophysicaActa 773, 32-38. 
[16] Iwu MM (1984). In proceedings of 4th Annual Conference of Nigeria Society of Pharmacognosy, University of Nigeria, Nsukka, In: The state of Medicinal Plant Research in Nigeria. Edited by Abayomisofowora. p.57.

[17] Jowell. T.(1999)In:Herbal Medicines. House of Commons official report (Hansard), 26, 426-427

[18] Karamac, M. In vitro study on efficacy of tannin fractions of edible nuts as antioxidants. Eur. J. Lipid Sci. Technol. 2009, 111, 10631071.

[19] Kolawole OM, Olayemi AB (2003). Studies on the efficacy of Brideliaferrugineabenth bark extract for water purification. Niger. J. PureAppl. Sci., 18: 387-1394.

[20] Lammi-Keefe, C J; P.B Swan, and P. V. J. Hegarty(1984) Effect of Level of Dietary Protein and Total or PartialStarvation on Catatase and Superoxide DismutaseActivity in Cardiac and Skeletal Muscles in Young Rats. J. Nutr. 114: 2235-2240,

[21] Lavin S. R., Chen Z., Abrams S.A. (2010). Effect of taninic acid on iron in straw-coloured fruit bats (Ediolonhelvum); Zoo Biol. 29, (3): 335-45.

[22] Lotikar JJ and Rajarama-Rao MR (1966): Pharmacology of hypoglycemic principle isolated from fruits of brudeliaferruginea. Indian Journal of Pharmacology 28(5): 129-133

[23] Marklund, S. L. and Marklund, G. (1974)Involvement of the superoxide anion radical in the autoxidation of pyrogallol and a convenient assay for superoxide dismutase.Eur. J. Biochem., 47, 469-474

[24] Mukuru Sam Z., Larry G, Butler, John C. Rogler, Alan W Kirleis, GebisaEjeta, John D. Artell and Edwin T. Mertz. (1992). Trditional Processing of High-Tannin Sorhum Grain in Uganda and Its effect on Tannin, Protein Digestibility and Rat Growth; J. Agric, Food Chem., 40 (7), pp 1172-1175.

[25] Reshef, G; B Gestetner, Y Birk, and A Bondi, (2006). Effect of alfalfa saponin on the growth and some aspect of lipid metabolism of mice and quails; Journal of Science of Food and Agricultutre, Vol. 27, Issue 1 pg. 63-72.

[26] Sinha, A.K., 1972. Colorimetric assay of catalase. Anal. Biochem., 47: 389-394.

[27] Sofowora EA (1982). Screening Plants for bioactive agents in medicinal plants and traditional medicine in Africa:EdAdedokun,oOlumeko,A and Adejobi,S Spectrum boob ltd pp181-208.

[28] Takechi M, \& Tanaka Y (1995) Haemolytic and time course differnces between steroids and triterpenoidssaponins. PlantaMedica 61, $76-77$.

[29] Vashney, R. and R.F. Kale, 1990. Effect of calmodulin antagonists on radiation induced lipid peroxidation in microsomes. Int. J. Radiat. Biol., 58: 733-743. 